\title{
A LITERATURA, O MERCADO e o canto da sereía
}

Vera Lúcia Follain de Figueiredo

A primeira crônica, publicada por João Ubaldo Ribeiro, no jornal O Globo, no ano $2000, \operatorname{logo}$ após o réveillon, gira em torno da relação entre arte e dinheiro. $\mathrm{O}$ escritor baiano, em tom irônico, manifesta sua profunda irritação diante do fato de muitas pessoas teimarem em não considerar a atividade artística como um trabalho digno de remuneração como qualquer outro, pois veriam o artista como um ser especial, escolhido pelas musas, diferente do comum dos homens e, portanto, acima dos interesses materiais. Essas mesmas pessoas, segundo João Ubaldo, seriam aquelas que acusariam o escritor de prostituição, de tornar-se um mercenário vil, seduzido pelo canto da sereia do mercado, quando este se revela preocupado com a venda de seus livros ou aceita escrever por encomenda. Para fundamentar a sua defesa contra o "país que se apega a essas noções atrasadinhas", nosso autor cita o exemplo de vários artistas consagrados que não perdiam de vista a recompensa financeira de seus trabalhos, como Shakespeare, Balzac, Dickens e lembra que Rembrandt, Goya, Michelangelo e Oscar Niemeyer também criaram por encomenda.

A crônica de João Ubaldo Ribeiro traz à tona uma questão que nos parece central para pensar os rumos da ficção literária contemporânea não só no Brasil, mas também no contexto mais amplo da cultura ocidental: a relação entre arte e mercado. Poderíamos dizer que essa questão vem se tornando cada vez mais importante, quan- 
do se trata de refletir sobre o processo de criação da narrativa de ficção brasileira das duas últimas décadas, em meio à grande pluralidade de vertentes que a caracteriza. Remete para o solo comum de onde se ergue um quadro heterogêneo que inclui desde um romance neo-naturalista, como Cidade de Deus, de Paulo Lins, até uma narrativa como Teatro, de Bernardo Carvalho, em que a textualidade auto-referencial dilui as fronteiras entre o real e a ficção. O que se quer dizer é que, por mais variados que sejam os estilos, as linguagens das obras que convivem no atual cenário da literatura, todas elas estão sendo produzidas num momento em que se redefinem as regras que a modernidade traçara para o campo literário.

A situação, hoje, é simetricamente oposta à que ocorreu na França, ao longo da segunda metade do século XIX, quando a relação entre a esfera da alta cultura e as esferas industrial e econômica também suscitou inúmeras discussões, mas, ao contrário do que se passa em nossos dias, foi colocada em pauta por aqueles que estavam interessados em afirmar a autonomia da arte face às leis do mercado. A estética moderna surge, na Europa, como resultado da luta para marcar as fronteiras entre o campo da arte e o da cultura de massa, que nasce comprometida com os avanços tecnológicos e com a progressiva mercantilização da cultura. É a permanência de critérios valorativos ligados a separação rígida entre esses dois campos, que João Ubaldo Ribeiro combate em sua crônica pós-réveillon, rejeitando a oposição entre valor artístico e cifras comerciais, que, a partir de determinado momento, passou a hierarquizar a produção de bens culturais, definindo novas regras de legitimação da arte no mundo ocidental. Diz, então, João Ubaldo:

E, infelizmente, faço parte do time nefando que gosta de que seus livros vendam bem. Na minha opinião, talvez consolo para uma posição indefensável, só existe dois tipos de arte básicos: a boa e a ruim. Tanto uma quanto outra podem obter sucesso no mercado, a depender de muitos fatores, o menos importante dos quais é a opinião dos críticos.

O autor menciona romancistas consagrados do século XIX europeu que viviam da venda de seus livros, mas naturalmente deixa de se referir a autores como Baudelaire e Flaubert, para os quais a sobrevivência da arte dependia da negação da face mercadológica e consumista da modernidade burguesa e, portanto, estava condicionada à ruptura com os valores ditados pela esfera dos negócios, o que exigia do artista um certo grau de desprendimento. Como observou Michel Foucault, é no exato mo- 
mento em que os discursos se tornam um produto, um bem, e o autor é integrado no sistema de propriedade que a possibilidade de transgressão desses valores adquire uma aura, o que vai levar Flaubert a declarar:

Quanto mais se põe consciência em seu trabalho, menos se tira lucro dele. Sustento esse axioma com a cabeça sob a guilhotina. Nós somos operários de luxo; ora, ninguém é bastante rico para pagar-nos. Quando se quer fazer dinheiro com sua pena, é preciso fazer jornalismo, folhetim ou teatro (Bourdieu, 101).

É esta atitude de emancipação face às exigências das diversas esferas do poder e, sobretudo, do poder econômico, que, até hoje, costuma ser cobrada dos escritores, na falta de estabelecimento de um outro critério de legitimação da literatura, sobretudo quando o autor se coloca numa posição ambígua, isto é, quando em alguns aspectos se apresenta como defensor das utopias modernas e, em outros, levanta a bandeira do pragmatismo pós-moderno. Até bem pouco tempo, no caso do Brasil, a ausência de um público consumidor de bens culturais mais amplo e o engajamento do escritor em causas sociais e políticas colocaram em segundo plano a problematização das relações entre arte e dinheiro. Esta vem se intensificando a partir das três últimas décadas, em função das mudanças ocorridas no mercado editorial e da progressiva descrença, tanto por parte dos artistas, quanto por parte do público, no papel revolucionário que a tradição de militância conferia ao intelectual. Entre nós, a discussão em torno da autonomia da arte torna-se importante quando, na ausência do componente utópico, o atingir as massas não se justificaria mais pelo sentido de missão, não se explicaria pela intenção de conscientizar as camadas populares e, portanto, poderia ser motivado pelo desejo de lucro, em nome do qual se sacrificaria a qualidade da obra, pelas concessões feitas a um gosto padrão. Assim, quando João Ubaldo diz que o "inatacável” Graciliano Ramos escreveu Vidas Secas "para descolar um tutuzinho em jornal”, a alusão não surte o efeito pretendido, já que a imagem que se construiu do intelectual Graciliano Ramos está ligada ao envolvimento com causas coletivas, com grandes ideais de justiça social, o que coloca em outros termos as questões relativas à sua sobrevivência material, além do que não há nada no romance citado, que possa nos levar a suspeitar de uma atitude de concessão à leveza característica das obras preocupadas em agradar um grande número de leitores.

As próprias soluções estéticas adotadas por grande parte dos autores contemporâneos refletem uma ambigüidade de propósitos característica das fases de transi- 
ção de valores. De um lado, são utilizados esquemas de composição que remetem para gêneros mais populares. De outro, se elabora o desenredo, dialogando com outros códigos - filosófico, cultural, semiótico. A ficção procura se oferecer a uma dupla leitura: uma que satisfaz a sede de entretenimento e outra que exige do leitor sofisticado a astúcia de ir além das facilidades aparentes. A solução híbrida adotada implica tentar conciliar, no interior de uma mesma obra, os dois pólos entre os quais ela se debate - as exigências do mercado e a rejeição a uma completa subordinação às suas leis. Busca-se, então, o romance policial, mas tenta-se evitar que toda a sua fruição seja submetida à revelação final da verdade sobre o crime. Busca-se o romance histórico mas, de preferência, incluindo alusões intertextuais para que o leitor mais esperto possa se satisfazer com a visão semiotizada da história.

A tensão vivida pelo escritor, dividido entre os apelos do mercado e os critérios de legitimação da literatura traçados pela modernidade estética, que a crônica de João Ubaldo deixa transparecer, tem sido tematizada por vários autores. A obra de Rubem Fonseca, por exemplo, traz para o universo ficcional todo um questionamento das relações do escritor com o mercado. Gustavo Flávio, personagem narrador de Bufo \& Spallanzani, é um escritor profissional que vive atormentado com as cobranças do editor.

Este é, também, o tema do conto Romance Negro, onde uma trama policial de superfície, capaz de seduzir o leitor incauto, se sobrepõe ao verdadeiro crime: aquele cometido pelos editores que, ávidos de lucros certos e sem riscos, matam a possibilidade de surgimento de novos talentos. $\mathrm{O}$ assassinato confessado pelo escritor John Landers, que, para conseguir a publicação de seus livros, mata Peter Winner, autor famoso de romances policiais, e assume sua identidade, é uma pista falsa. Primeiro porque, em sua individualidade particular, Winner já não existia para o público. Era apenas o escritor que não gostava de aparecer, sobre o qual pairavam suspeitas de homossexualismo e que se orgulhava de não ter biografia. O seu nome não reenviava o leitor para um indivíduo real, exercia o que Foucault chama de "função autor", isto é, servia para conferir um certo estatuto à obra, para avalizar o seu valor, por isso, era antes de mais nada um lugar que poderia ser ocupado por diferentes eus, inclusive por Landers.

O conto é uma alegoria da morte do autor enquanto realidade empírica, enquanto nome próprio, já que o nome do autor passa a ser um dispositivo classificatório, caracterizando um modo de ser do discurso no interior da sociedade, conferindo "uma certa unidade de escrita pelo que todas as diferenças são reduzidas pelos princípios da 
evolução, da maturação e da influência (Foucault, 53)". Assim, ao perceber mudanças no romance assinado por Winner que teria sido escrito por Landers, um editor interpreta as diferenças como uma recurso do escritor para renovar a própria obra, como um corte radical mas que não chega a abalar a unidade da obra.

Se o assassinato de Winner ocorreu ou não é algo que não tem nenhuma importância para a problemática central do conto, porque, em sua identidade pessoal, ele já estava morto para o público e fora substituído por uma espécie de marca a serviço dos interesses comerciais da editora. Da mesma forma, se Landers é uma outra pessoa e não um alter-ego do próprio Winner, não é, de fato, relevante porque Landers também deixou de existir, como escritor, ao assumir o nome de Winner, ou seja, como diz Foucault, "seria tão falso procurar o autor no escritor real quanto no locutor fictício (Foucault, 55)".

O grande crime é cometido pela personagem Clotilde, a editora, quando não lê os livros que lhe são enviados por desconhecidos, pois não teria, ao publicá-los, a garantia de lucro. Assim, priva esses escritores, enquanto escritores, de existência, condenando-os ao anonimato em função da lógica comercial que privilegia a repetição em detrimento da renovação. Nesse esquema comandado pelo mercado, os talentos individuais são tragados pelas leis do sistema de produção e circulação de mercadorias, que acaba por envolver também os críticos e por transformar os congressos literários em grandes feiras de exposição de produtos.

Da mesma forma, o conto "O Duelo", de Sérgio Sant'Anna, refere-se ao embate entre um escritor em início de carreira e um editor bem sucedido. O texto, como o próprio título sugere, coloca escritor e editor em posições opostas e conflitantes: de um lado, a altivez, a superioridade arrogante de quem se sente vitorioso e tem o poder de veto; de outro, o orgulho ferido e a insegurança daquele que submete um trabalho a julgamento, ainda mais considerando que a instância julgadora, pelo caráter comercial, teria legitimidade duvidosa aos olhos de um "vanguardista nostálgico". De um lado, a vaidade e os desejos pessoais do editor, encobertos por uma pseudo-objetividade profissional: de outro, a vocação para o fracasso do escritor que, no fundo, orgulha-se de sua condição marginal e, militante da recusa, desconfia do sucesso que levaria a uma cooptação pelo sistema. Face à vocação "heró́ca" do escritor maldito, o editor contrapõe o exemplo do famoso autor americano Malcom Montgomery:

Isso foi no tempo em que ele tomava drogas, os anos utópicos, idealistas. Mas a vanguarda acabou, é chata, demodée, provinciana. A literatura comercial do novo 
Montgomery é uma opção e um estilo, inclusive de vida. Tornar-se normal, um escritor de enredos fortes para o leitor comum, mas que permite ao leitor sofisticado uma outra perspectiva, está aí a verdadeira ironia, essencial, sem idiossincrasias, literatura (ele riu) (Sant'Anna, 11).

E mais adiante acrescenta:

Também aqui, agora, todos só pensam em dinheiro, adiantamentos, profissionalismo literário, esse negócio todo. E o pior é que não conseguem mais do que migalhas, ha, ha, ha, a troco de piorar ainda mais a sua coisa escrita, já por si menor (23).

Nos dois contos citados, fica evidente a sintomática proeminência, o agigantamento da figura do editor, no lugar do diálogo com o leitor, como vemos, por exemplo, nos romances de Machado de Assis, nos quais o questionamento do padrão de gosto comum também está presente, mas o alvo da crítica e das estratégias de conquista ainda é o leitor. Hoje, a literatura, que já há algum tempo, devido à crise de representação, à descrença no poder das palavras, tem se voltado sobre si mesma, tematizando a sua própria condição de jogo, se volta para os mecanismos de produção, distribuição e divulgação de seus produtos: ora para afirmar a diluição das fronteiras do campo da arte no universo mais amplo da produção cultural, ora para trazer à tona a tensão vivida pelo escritor diante desse quadro. Sob pena de obedecer ou sucumbir ou de obedecer e, assim mesmo, sucumbir, afogada no mar de narrativas de puro entretenimento que nos cerca, a obra de ficção encena os impasses do autor em nossos dias, quando publicar não significa ainda furar as barreiras do anonimato, como também não basta simplesmente aceitar as regras do jogo e conceder ao gosto da maioria para atingir o sucesso, como disse o personagem de Sérgio Sant'Anna. Entre escritor e público, não existe mais uma simples relação de troca comercial, há toda uma série de mediações que acompanha a indústria editorial contemporânea, há uma mídia poderosa que torna inadequada a comparação com Shakespeare e seus shillings recolhidos na entrada do teatro.

A questão, hoje, não se resume na discussão em torno dos aspectos positivos ou negativos da profissionalização do escritor, para a sobrevivência da literatura, mas aponta para a dificuldade de conciliar o pragmatismo do mercado, que cada vez mais, com seu ritmo frenético, se alimenta de objetos descartáveis, com a vontade de dura- 
ção, de transcendência no tempo que sempre marcou o trabalho artístico, conferindolhe um lugar específico na sociedade, assegurando-lhe o papel de preservação da memória de uma cultura. Se a arte já não pode ser a "outra voz”, enquanto expressão do espírito crítico de uma elite burguesa, ou de uma vanguarda heróica que o ocaso das antigas utopias tornou inviável, se abriu mão da negatividade moderna, tem, agora, a tarefa de descobrir como vai conciliar a vocação para a permanência que sempre a caracterizou e que ainda a habita, com a voracidade do consumo, que redefine o tempo como um eterno aqui e agora, onde a própria memória tende a ser consumida.

\section{$\operatorname{son}$}

\section{REFERÊNCIAS BIBLIOGRÁFICAS}

BOURDIEU, Pierre. As regras da arte. Trad. Maria Lúcia Machado. S.Paulo: Cia das Letras, 1996.

FONSECA, Rubem. Romance Negro. In: Romance Negro. S.Paulo: Cia das Letras, 1992.

FOUCAULT, Michel. O que é um autor?. Trad. Antônio Fernando Cascais e Edmundo Cordeiro. Vega, 1992. PAZ, Octavio. A outra voz: S.Paulo: Siciliano, 1993.

RIBEIRO, João Ubaldo. De olho no mercado. O Globo, Rio de Janeiro, 2 jan. 2000. Primeiro Caderno, p.7. SANT'ANNA, Sérgio. O Duelo. In: A Senhorita Simpson. S.Paulo: Cia das Letras, 1989.

Vera Lúcia Follain de Figueiredo é Professora da PUC-Rio. Formada em Letras pela UFRJ, Mestre e Doutora em Letras pela PUC-Rio. Publicou, dentre outros livros: Da profecia ao labirinto: imagens da bistória na ficção latino-americana contemporânea e Mídia e educação (org.). É Pesquisadora do CNPq. 